\title{
Adrenal-pituitary-gonadal relationships and ejaculate characteristics in captive leopards (Panthera pardus kotiya) isolated on the island of Sri Lanka
}

\author{
J. L. Brown*, D. E. Wildt $\dagger$, L. G. Phillips $\ddagger$ J. Seidensticker $\ddagger$, \\ S. B. U. Fernando§, S. Miththapala $\ddagger$ and K. L. Goodrowe
}

Departments of $*$ Obstetrics and Gynecology, and $\uparrow$ Physiology, Uniformed Services University of the Health Sciences, Bethesda, MD 20814, USA; $\ddagger$ National Zoological Park, Smithsonian Institution, Washington, DC 20008, USA; §Department of National Zoological Gardens, Dehiwala, Sri Lanka; and $\uparrow$ Metro Toronto Zoo, Ontario, Canada MIE $4 R 5$

\begin{abstract}
Summary. In Study 1, semen was collected using a standardized electroejaculation procedure. Males $(\mathrm{N}=8)$ produced ejaculates with a high incidence of sperm abnormalities $(77 \pm 3 \cdot 3 \%)$. After electroejaculation under anaesthesia, serum cortisol concentrations increased $(P<0.05)$, while testosterone concentrations decreased $(P<0.05)$ and LH and FSH concentrations were unchanged $(P>0.05)$ over a 2-h bleeding period. In Study 2, male and female leopards were bled at 5-min intervals for $3 \mathrm{~h}$ and given (i.v.): (1) saline ( $\mathrm{N}=2 / \mathrm{sex}$ ); (2) $\mathrm{GnRH}(1 \mu \mathrm{g} / \mathrm{kg}$ body weight) $30 \mathrm{~min}$ after the onset of sampling $(\mathrm{N}=5 / \mathrm{sex})$; or (3) ACTH $(250 \mu \mathrm{g})$ at $30 \mathrm{~min}$ followed by GnRH $1 \mathrm{~h}$ later $(\mathrm{N}=5 / \mathrm{sex})$. Basal concentrations of serum $\mathrm{LH}$, FSH and cortisol were comparable $(P>0.05)$ between male and female leopards. After GnRH, peak LH concentrations were 2 -fold greater $(P<0.05)$ in males than females while FSH responses were similar. In males, testosterone concentrations increased 2-3-fold following GnRH. After ACTH, serum cortisol concentrations doubled within $15 \mathrm{~min}$ in both sexes. Administration of ACTH $1 \mathrm{~h}$ before GnRH did not affect GnRHinduced LH or FSH release $(P>0.05)$; however, testosterone secretion was only $30 \%$ of that observed after GnRH alone $(P<0.05)$. We conclude that $(1)$ the high incidence of sperm abnormalities in the leopards of Sri Lanka may be related to parallel findings of genetic homozygosity; and (2) decreases in basal and GnRH-stimulated testosterone secretion were related to increases in serum cortisol after electroejaculation or ACTH and were not associated with changes in pituitary gonadotrophin secretion.
\end{abstract}

Keywords: leopard; spermatozoa; GnRH; ACTH; LH; FSH; cortisol; testosterone

\section{Introduction}

In the Family Felidae, a data base of endocrine and ejaculate norms and their relationship to various environmental and genetic factors is gradually being developed. Of particular interest is the finding of species-specific variations in the incidence of teratospermia as well as differences in circulating concentrations of glucocorticoids (Wildt et al., 1983, 1984b, 1988; Howard et al., 1984a). Among large-sized felids, the anaesthetized North Chinese leopard (Panthera pardus japonensis) appears to differ by secreting high concentrations of cortisol in the presence of consistently acute decreases in serum testosterone without concomitant decreases in LH (Wildt et al., 1988). Although we have suspected for years that acute increases in stress-related hormones, such as cortisol, adversely affect gonadal function in wild felids, direct evidence is lacking. The incidence of 
pleiomorphic spermatozoa is also high in this subspecies, although this finding has not been directly associated with either hyperadrenal activity or a compromised genotype.

There are at least 27 recognized subspecies of leopard distributed throughout Africa and Asia (Ellerman \& Morrison-Scott, 1951; Smithers, 1971). Although the leopard exists in a wide range of habitats and occupies a broad niche compared to other felids, the species is considered endangered in Asia (Seidensticker et al., 1989). One subspecies, $P$. p. kotiya, found on the island of Sri Lanka is 1 of 3 world-wide extant island populations (Deraniyagala, 1949, 1956). The National Zoological Gardens of Sri Lanka at Dehiwala currently maintains about 40 wild-caught and captive-born individuals under similar environmental and managerial conditions. This situation offered a unique opportunity to study ejaculate characteristics and the relationship of adrenal activity to pituitary and gonadal function in a presumably homogeneous population of an endangered species. A simultaneous survey of the genetic diversity of these leopards (utilizing electrophoretic analyses of blood isoenzymes) allowed a comparison of seminal-endocrine characteristics with genetic variability, similar to previous efforts in the cheetah (Acinonyx jubatus) (O'Brien et al., 1985) and geographically-isolated African ( $P$. leo leo) and Asian lion (P. l. persica) (O'Brien et al., 1987; Wildt et al., 1987). The specific objectives were 2-fold: (1) to determine ejaculate characteristics including the incidence of teratospermia; and (2) on the assumption that acute stressors may affect pituitary or gonadal function, exogenous $\mathrm{GnRH}$ and adrenocorticotrophin (ACTH) were used to investigate the impact of adrenal-stimulated corticosteroid production on gonadotrophin release in males and females and testosterone secretion in males.

\section{Materials and Methods}

Animal maintenance and anaesthesia. Male and female leopards, maintained in indoor-outdoor enclosures were studied in February and March of 1987. It is not known whether the leopards of Sri Lanka undergo seasonal reproduction. In Africa and India, leopards are known to mate throughout the year while in Manchuria and eastern Siberia a prominent mating season has been observed in January and February (Guggisberg, 1975).

For semen collection and blood sampling, animals were anaesthetized with a combination of tiletamine hydrochloride and zolazepam hydrochloride (Zoletil: Laboratoire Virbec, Nice, France; $46 \mathrm{mg} / \mathrm{kg}$, i.m.) delivered via blow dart. Once tractable, each animal was immediately transported $\sim 0.25 \mathrm{~km}$ to the veterinary facility and weighed. Immobilization was maintained with supplemental Zoletil injections (50-100 mg i.m.).

Study 1 . Eight males which had sired at least 1 litter (proven males) were used for analysis of seminal-endocrine characteristics. Four males were wild caught, 2 were captive born and 2 were of unknown origin. Males ranged in age from 3 to 10 years (average $8.3 \pm 1.8$ years) and their mean body weight was $63.1 \pm 2.6 \mathrm{~kg}$. Three males were housed as a group, 3 were paired with a female and 2 were housed singly.

Semen was collected by a standardized electroejaculation technique (Wildt et al., 1983, 1986b, 1988; Howard et al., 1986) using an electrostimulator (P-T Electronics, Boring, OR, USA) and rectal probe. The regimented sequence consisted of a total of 80 incremental stimuli ( $3 \mathrm{sec}$ on, $3 \mathrm{sec}$ off) given in 3 series. Series I and II consisted of 30 stimuli each, divided into 3 sets of 10 stimuli at 5,6 and $7 \mathrm{~V}$ (Series I) and 6,7 and $8 \mathrm{~V}$ (Series II). Then 20 stimuli were administered in Series III, with 10 stimuli each at 7 and $8 \mathrm{~V}$. Semen from each series was evaluated qualitatively for percentage motility and progressive status (speed of forward progression based on a scale of $0=$ no movement, to $5=$ rapid forward movement) (Howard et al., 1984b). Gross morphological assessments were made by fixing a $100 \mu \mathrm{l}$ semen sample from each collection series in $500 \mu$ l glutaraldehyde $(1 \% \mathrm{v} / \mathrm{v}$ in saline) and later evaluating 300 spermatozoa/ejaculate using phase contrast microscopy ( $\times 1000$ under oil) (Pursel \& Johnson, 1974; Howard et al., 1986). For each male, there were no differences $(P>0.05)$ in ejaculate characteristics among the 3 collection series; therefore, semen data within males were averaged for presentation.

Blood samples were obtained by saphenous venepuncture immediately before the onset of electroejaculation, after each electroejaculation series and at $15,30,45,60,75$ and $90 \mathrm{~min}$ after the last electrical stimulus ( 10 samples/male). All samples were maintained at $5^{\circ} \mathrm{C}$ for $\sim 1 \mathrm{~h}$ before centrifugation. Recovered sera were stored at $-20^{\circ} \mathrm{C}$ until analysed.

Study 2. Twelve female leopards and 12 male leopards not utilized in Study 1 were used to study the effects of ACTH and GnRH on pituitary-gonadal responses. With the exception of 2 males and 1 female, all animals were captive born. Of the males, 5 were maintained as singletons, 2 were housed together and 5 were paired with a female. Three females were maintained as singletons, 3 were housed together and 6 were paired with a male. All animals in Studies 1 and 2 had visual, auditory and/or olfactory contact with conspecifics of both sexes. Males in this study were not breeders (unproven males) and only one female had given birth to a single litter. Body weight for males averaged $54 \pm 2.5 \mathrm{~kg}$ and age ranged from 3 to 10 years (average $6.1 \pm 1$ years). Mean female body weight was $36.8 \pm 1.5 \mathrm{~kg}$ and age ranged from 3 to 10 years (average $5.5 \pm 1.3$ years). 
Immediately after induction of anaesthesia and transport to the veterinary facilities, a 16-gauge, 5-cm indwelling cannula (Becton Dickinson, Rutherford, NJ, USA) was placed into a saphenous or lateral coccygeal vein. Blood sampling was initiated within $30 \mathrm{~min}$ after the initial injection of anaesthetic.

Animals were assigned at random and treated (i.v.) with: (1) saline (0.154 M- NaCl, $\mathrm{pH} 6.9 ; 2 \mathrm{ml})$ administered after 30 min of sampling ( 2 males, 2 females); (2) GnRH ( $1 \mu \mathrm{g} / \mathrm{kg}$ body weight; Gonadorelin, Abbott Labs, Chicago, IL, USA) delivered via the cannula after 30 min of sampling (GnRH; 5 males, 5 females); or (3) ACTH (250 $\mu$; Cortrosyn, Organon, Inc., W. Orange, NJ, USA) administered at $30 \mathrm{~min}$, followed $\mathrm{I}$ h later by GnRH (ACTH/ GnRH; 5 males, 5 females). Blood samples $(3 \mathrm{ml})$ were collected at $5 \mathrm{~min}$ intervals for $3 \mathrm{~h}$ and sera recovered and stored as described for Study 1. To confirm that males used in Study 2 were spermatogenic, a single electroejaculate was collected immediately after the last blood sample. The technique utilized was the same as that described for Series I in Study 1.

Radioimmunoassays. Serum LH and FSH concentrations were quantified using specific radioimmunoassays previously validated for leopard serum (Brown et al., 1988), using dog LH (LER-1685-1) and sheep FSH (NIH-FSHS8) as the reference standards. Assay sensitivities (defined as $95 \%$ of maximum binding) were 0.7 and $10 \mathrm{ng} / \mathrm{ml}$ for $100 \mu \mathrm{l} \mathrm{serum}$; inter- and intra-assay coefficients of variation for $100 \mu \mathrm{l}$ of a serum pool $(\mathrm{N}=10)$ were 8.1 and $6 \cdot 5$, and 8.5 and $5.9 \%$ for LH and FSH, respectively. The 20,50 and $80 \%$ binding values of the dog LH standard curve were $40.5,4.9$ and $1.1 \mathrm{ng} / \mathrm{ml}$, and of the sheep FSH standard curve were 164,51 and $15 \mathrm{ng} / \mathrm{ml}$, respectively.

Testosterone was measured in unextracted serum using a double-antibody ${ }^{125} \mathrm{I}$ radioimmunoassay kit (Radio Systems Laboratories, Carson, CA, USA). The primary antiserum (rabbit anti-testosterone-19-carboxymethyletherbovine serum albumin) had the following cross-reactivities (determined as the cross-reactivity at $50 \%$ displacement compared to testosterone): $100 \%$ with testosterone; $10-3 \%$ with $5 \alpha$-dihydrotestosterone; $<1 \%$ with $5 \beta$-dihydrotestosterone, androstenedione, androsterone, epiandrosterone, oestrone, oestradiol-17 $\beta$, oestriol, progesterone and corticosterone. The assay was validated for leopard serum by demonstrating recovery of mass. Upon addition of $0 \cdot 125$, $0 \cdot 25,0 \cdot 5,1 \cdot 25,2.5$ and $5 \mathrm{ng}$ testosterone to $50 \mu \mathrm{l}$ leopard serum, $0 \cdot 11,0 \cdot 24,0 \cdot 49,1 \cdot 18,2.45$ and $4.97 \mathrm{ng}$ were recovered, respectively, after subtraction of endogenous hormone $(y=-0.024+0.996 x ; r=0.999)$. Inhibition curves for pooled sera and the testosterone standard were paraltel. Assay sensitivity was $0.05 \mathrm{ng} / \mathrm{ml}$ for $50 \mu \mathrm{l}$ serum and the interand intra-assay coefficients of variation for $50 \mu \mathrm{l}$ samples of a serum pool were $5 \cdot 5$ and $4.6 \%$, respectively. The 20,50 and $80 \%$ binding values of the testosterone standard curve were $7 \cdot 9,0.9$ and $0.2 \mathrm{ng} / \mathrm{ml}$, respectively.

Cortisol was measured in unextracted serum using a double antibody ${ }^{125}$ I radioimmunoassay kit (New England Nuclear, N. Billerica, MA, USA). The antiserum complex (rabbit cortisol antibody prereacted with rabbit gammaglobulin antiserum) had the following cross-reactivities: $100 \%$ with cortisol; $62.8 \%$ with prednisolone; $14.7 \%$ with corticosterone; $4.3 \%$ with 11-deoxycortisol; $3.5 \%$ with $17 \alpha$-hydroxyprogesterone; $1.9 \%$ with 11 -deoxycorticosterone; $1.6 \%$ with cortisone; $1.6 \%$ with progesterone; $<1 \%$ with testosterone, dihydrotestosterone, oestradiol- $17 \beta$ and aldosterone. Because of high cortisol concentrations, sera were diluted $1: 1$ with PBS buffer $\left(0 \cdot 01 \mathrm{M}-\mathrm{NaPO}_{4}, 0 \cdot 154 \mathrm{M}-\right.$ $\mathrm{NaCl}, \mathrm{pH} 7.2$ ) before analysis. The assay was validated for use with leopard serum. Recovery estimates after subtraction of endogenous hormone from the analysis of $10,25,50$ and $125 \mathrm{ng}$ cortisol in $10 \mu 1$ serum were 8,29,58 and $143 \mathrm{ng}$, respectively, $(y=-1.45+1.16 x ; r=0.996)$. Inhibition curves for serum pools were parallel to the standard curve. Sensitivity was $7.5 \mathrm{ng} / \mathrm{ml}$ for $10 \mu \mathrm{l}$ serum and inter- and intra-assay coefficients of variation were 8.8 and $5.8 \%$ for $10 \mu \mathrm{l}$ samples of a serum pool, respectively. The 20,50 and $80 \%$ binding values of the cortisol standard curve were 492,107 and $29 \mathrm{ng} / \mathrm{ml}$, respectively.

The ${ }^{125}$ I steroid RIA kits described above were developed for use with unextracted human serum. Analysis of extracted and unextracted leopard serum poois $(n=10)$ yielded similar results. Therefore, all serum samples were assayed unextracted.

Data analysis. Changes in endocrine values over time were analysed using split-plot analyses of variance. Gonadotrophin responses to $\mathrm{GnRH}$, testosterone responses to $\mathrm{LH}$ and cortisol responses to ACTH were evaluated as peak height, net peak height (greatest post-treatment value minus mean pretreatment level) and net area under the response curves. Net area after hormone treatment, expressed as $\mathrm{cm}^{2} / 90 \mathrm{~min}$ ( $\mathrm{LH}$, FSH and testosterone) or $\mathrm{cm}^{2} /$ $150 \mathrm{~min}$ (cortisol), was determined using a planimeter with a $3 \%$ coefficient of variation (Brown et al., 1988). Differences in endocrine data between sexes or GnRH vs ACTH/GnRH treatments were determined by Student's $t$ tests. Data are presented as means \pm s.e.m.

Basal and pulsatile serum hormone patterns were evaluated as described previously (Brown et al., 1988). Briefly, basal hormone concentrations were determined by an iterative process in which high values (those exceeding the mean plus 2 s.d.) were excluded). A pulse was significant if: (1) the amplitude was at least 2 standard deviations greater than the mean concentration; (2) the peak occurred within 2 samples of a previous nadir; and (3) the peak was followed by at least 2 successive values that were declining or represented baseline values. Pulse amplitude was defined as the highest point associated with the peak minus the mean basal concentration.

\section{Ejaculate characteristics}

\section{Results}

Among all Study 1 and 2 males, sperm concentration, \% motility and progressive status ratings were: $0 \cdot 3-74 \cdot 3 \times 10^{6}$ spermatozoa $/ \mathrm{ml} ; 20-85 \%$; and $2-4 \cdot 5$, respectively. Ejaculates from all males were characterized by a high percentage of abnormal spermatozoa (range, $45 \cdot 6-93 \cdot 5 \%$ ). The major 
sperm defect was a tightly coiled flagellum, although spermatozoa with an abnormal acrosome, bent midpiece, bent flagellum or cytoplasmic droplet were also prevalent (Table 1).

Table 1. Ejaculate traits of captive male leopards (Panthera pardus kotiya) in Studies 1 and 2

\begin{tabular}{|c|c|c|}
\hline & $\begin{array}{l}\text { Study } 1 \\
(N=8)\end{array}$ & $\begin{array}{l}\text { Study } 2 \\
(\mathrm{~N}=12)\end{array}$ \\
\hline \multicolumn{3}{|l|}{ Sperm concentration $/ \mathrm{ml}$} \\
\hline Motility (\%) & $55 \cdot 0 \pm 5 \cdot 2$ & $54 \cdot 0 \pm 2 \cdot 5$ \\
\hline Progressive status $(0-5)$ & $3 \cdot 3 \pm 0 \cdot 2$ & $3 \cdot 1 \pm 0 \cdot 2$ \\
\hline Normal spermatozoa $(\%)$ & $22.8 \pm 5.8$ & $19.9 \pm 2.5$ \\
\hline \multicolumn{3}{|l|}{ Abormality type $(\%)$} \\
\hline Microcephalic & $0.4 \pm 0.2$ & $0 \cdot 1 \pm 0 \cdot 1$ \\
\hline Bicephalic & $0.3 \pm 0.1$ & $0.4 \pm 0.2$ \\
\hline Abnormal acrosome & $12 \cdot 7 \pm 1 \cdot 8$ & $12 \cdot 2 \pm 3 \cdot 0$ \\
\hline Loose head & $0.9 \pm 0.7$ & $0.9 \pm 0.9$ \\
\hline Bent neck & $1.8 \pm 0.4$ & $3 \cdot 3 \pm 0.7$ \\
\hline Abnormal midpiece & $2 \cdot 0 \pm 0.4$ & $4 \cdot 1 \pm 1 \cdot 2$ \\
\hline Bent midpiece & $7 \cdot 2 \pm 1 \cdot 2$ & $7 \cdot 1 \pm 1 \cdot 3$ \\
\hline $\begin{array}{l}\text { Bent midpiece with } \\
\text { cytoplasmic droplet }\end{array}$ & $10 \cdot 8+1 \cdot 8$ & $8 \cdot 0+1 \cdot 3$ \\
\hline Bent flagellum & $5.4 \pm 0.9$ & $5.9 \pm 0.7$ \\
\hline Coiled flagellum & $22 \cdot 4 \pm 5 \cdot 3$ & $19.5 \pm 4.9$ \\
\hline $\begin{array}{l}\text { Proximal cytoplasmic } \\
\text { droplet }\end{array}$ & $7 \cdot 3 \pm 1 \cdot 2$ & $7 \cdot 9 \pm$ \\
\hline $\begin{array}{l}\text { Distal cytoplasmic } \\
\text { droplet }\end{array}$ & $5 \cdot 9 \pm 1 \cdot 3$ & $10 \cdot 8 \pm 3 \cdot 1$ \\
\hline
\end{tabular}

Values are mean \pm s.e.m.

\section{Endocrine characteristics}

Mean serum cortisol concentrations in Study 1 males increased $(P<0.05) 40 \%$ after the first electroejaculation series and were sustained at this level throughout the bleeding interval (Fig. 1). Serum testosterone concentrations decreased over time $(P<0.05)$ from $0.55 \pm 0.16 \mathrm{ng} / \mathrm{ml}$ before electroejaculation to $0.23 \pm 0.06 \mathrm{ng} / \mathrm{ml}$ in the final blood sample (Fig. 1). In contrast, neither serum LH nor FSH concentrations were altered $(P>0.05)$. In Study 2 , mean serum cortisol concentrations were not different $(P>0.05)$ between saline- and GnRH-treated leopards and so the results were pooled for presentation (Fig. 2a). Cortisol concentrations increased gradually (as much as $25 \%$ ) in about two-thirds of the saline- and GnRH-treated animals, usually within 70-120 min of blood sampling onset (Fig. 2a). After ACTH, serum cortisol doubled within 10-15 min of injection and remained elevated for the sampling duration (Fig. $2 b$ ). There were no differences $(P>0.05)$ in ACTH-induced cortisol responses between males and females.

Basal concentrations of LH $(1.9 \pm 0.2 ; 1.8 \pm 0.1 \mathrm{ng} / \mathrm{ml})$ and FSH $(28.7 \pm 7.8 ; 27.5 \pm 8.6 \mathrm{ng} /$ $\mathrm{ml})$ were similar $(P>0.05)$ between saline-treated male and female leopards, respectively. Pulses of LH (1-3 pulses $/ 180 \mathrm{~min}$ ) were detected in all control animals. Pulse amplitudes ranged from 1.0 to $1.8 \mathrm{ng} / \mathrm{ml}$ and averaged $1.3 \pm 0.1 \mathrm{ng} / \mathrm{ml}$. Pulses of FSH, based on previously described criteria, were not observed. After GnRH, serum LH concentrations peaked within 10-20 min, with maximal LH values being 2-fold greater $(P<0.05)$ in males than females (Fig. 3a). Serum FSH concentrations doubled in all animals within 15-30 min after GnRH and responses were similar $(P>0.05)$ between sexes. In males, increases in serum testosterone occurred within 15-30 min of the GnRH injection and values remained elevated 2.5-fold over baseline concentrations throughout the bleeding period (Fig. 3a). Administration of ACTH $1 \mathrm{~h}$ before GnRH did not affect $(P>0.05)$ pituitary release of LH or FSH, while testosterone secretion was less $(P<0.05)$ compared to that 

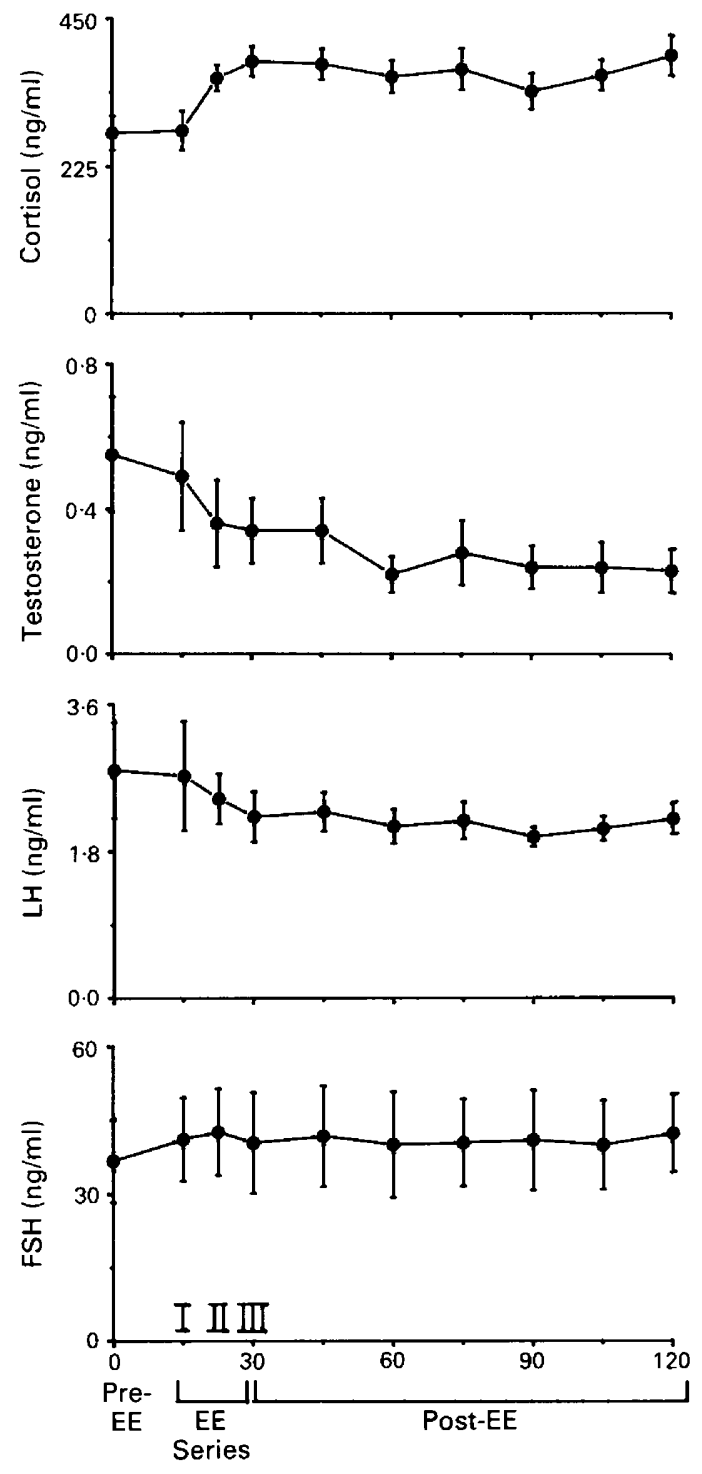

Minutes

Fig. 1. Mean \pm s.e.m. serum cortisol, testosterone, LH and FSH concentrations in Sri Lankan leopards $(\mathrm{N}=8)$ subjected to a standardized electroejaculation regimen. Pre-EE $=$ after anaesthesia, before electroejaculation; I, II and III = end of electroejaculation Series I, II and III, respectively. Post-EE = 15-min samples collected 15-90 min after electroejaculation.

observed after GnRH along (Fig. 3a, b). Testosterone peak height $(1 \cdot 80 \pm 0 \cdot 14$ vs $0 \cdot 81 \pm 0 \cdot 26 \mathrm{ng} /$ $\mathrm{ml})$, net peak height $(1.07 \pm 0.27$ vs $0.35 \pm 0.05 \mathrm{ng} / \mathrm{ml})$ and net area under the curve $(9.95 \pm 2.21$ vs $\left.2.92 \pm 0.64 \mathrm{~cm}^{2} / 90 \mathrm{~min}\right)$ were 2 - to 3-fold more $(P<0.05)$ in $\mathrm{GnRH}$-treated males than in those treated with ACTH + GnRH.

\section{Discussion}

The high serum cortisol concentrations obtained in this study were similar to those reported for the North Chinese leopard (Brown et al., 1988; Wildt et al., 1988), but were several-fold higher than 




Fig. 2. Mean \pm s.e.m. serum cortisol concentrations after injection of (a) saline ( 2 animals/sex) or GnRH (5/sex), or (b) ACTH (5/sex) in male $(\boldsymbol{\Delta})$ and female $(\boldsymbol{\square})$ leopards.

those found in other felids (Carter et al., 1984; Wildt et al., 1984b, 1988). In anaesthetized North Chinese leopards and pumas (Felis concolor), serum cortisol increases over time; however, concomitant decreases in serum testosterone are consistently observed only in the leopard (Wild et al., 1988). In the present study, serum cortisol elevations during electroejaculation were associated temporally with acute decreases in circulating testosterone. Furthermore, ACTH-induced elevations in serum cortisol had no influence on GnRH-stimulated LH or FSH release in either sex; however, testosterone secretion in response to $\mathrm{GnRH}$-induced $\mathrm{LH}$ release in males was significantly attenuated. These observations confirm an earlier suggestion that the influence of increased adrenal activity on pituitary-gonadal function among felids is species-specific (Wildt et al., 1988), and suggests that the leopard may be particularly sensitive to the influence of increased adrenal activity. The effect of increased serum cortisol concentrations on $\mathrm{LH}$ secretion in carnivores (including felids) is poorly understood. Reduced pituitary responsiveness to exogenous GnRH has been demonstrated after an elevation of corticosteroids in female rats (Baldwin \& Sawyer, 1974), rams (Matteri et al., 1984), gilts (Pearce et al., 1988) and boars (Liptrap \& Raeside, 1975). In contrast, Liptrap \& Raeside (1983) found that cortisol infusion increased pituitary response to GnRH in adult boars. Still others report no effect of elevated corticosteroids on either basal or GnRH-stimulated LH release (Barnes et al., 1983). Studies in primates have demonstrated that exogenous ACTH or glucocorticoids can markedly alter testosterone release without affecting basal or GnRH-stimulated gonadotrophin secretion (Doerr \& Pirke, 1976; Sapolsky, 1985). In rats, decreases in testosterone secretion have been related to a direct inhibitory effect of glucocorticoids on the testis since both dexamethasone and corticosterone reduce the concentrations of Leydig cell LH receptors (Saez et al., 1977; Bambino \& Hsueh, 1981). In agreement with these reports, the present study is the first to demonstrate that suppressed testicular function occurs after acute elevations of serum cortisol in a wild species of felid, without any observed perturbations in circulating $\mathrm{LH}$ or FSH.

Basal and pulsatile LH and FSH secretion in Sri Lankan leopards was similar to that reported for North Chinese leopards (Brown et al., 1988). Basal testosterone concentrations in Sri Lankan leopards were less than values reported for the domestic cat (F. catus), clouded leopard (Neofelis nebulosa), tiger (P. tigris) and puma (Goodrowe et al., 1985; Wildt et al., 1986b, 1988; Brown et al., 1988), but were similar to the lower values reported for the cheetah and North Chinese leopard (Wildt et al., 1984a, b, 1988; Brown et al., 1988). In this study, male and female leopards responded to GnRH with increases in serum LH and FSH that were nearly identical in magnitude to those described for North Chinese leopards (Brown et al., 1988). The LH response to GnRH was greater in males than females, although no gender differences in GnRH-stimulated FSH secretion were observed. Sex differences in GnRH-stimulated LH secretion have also been 

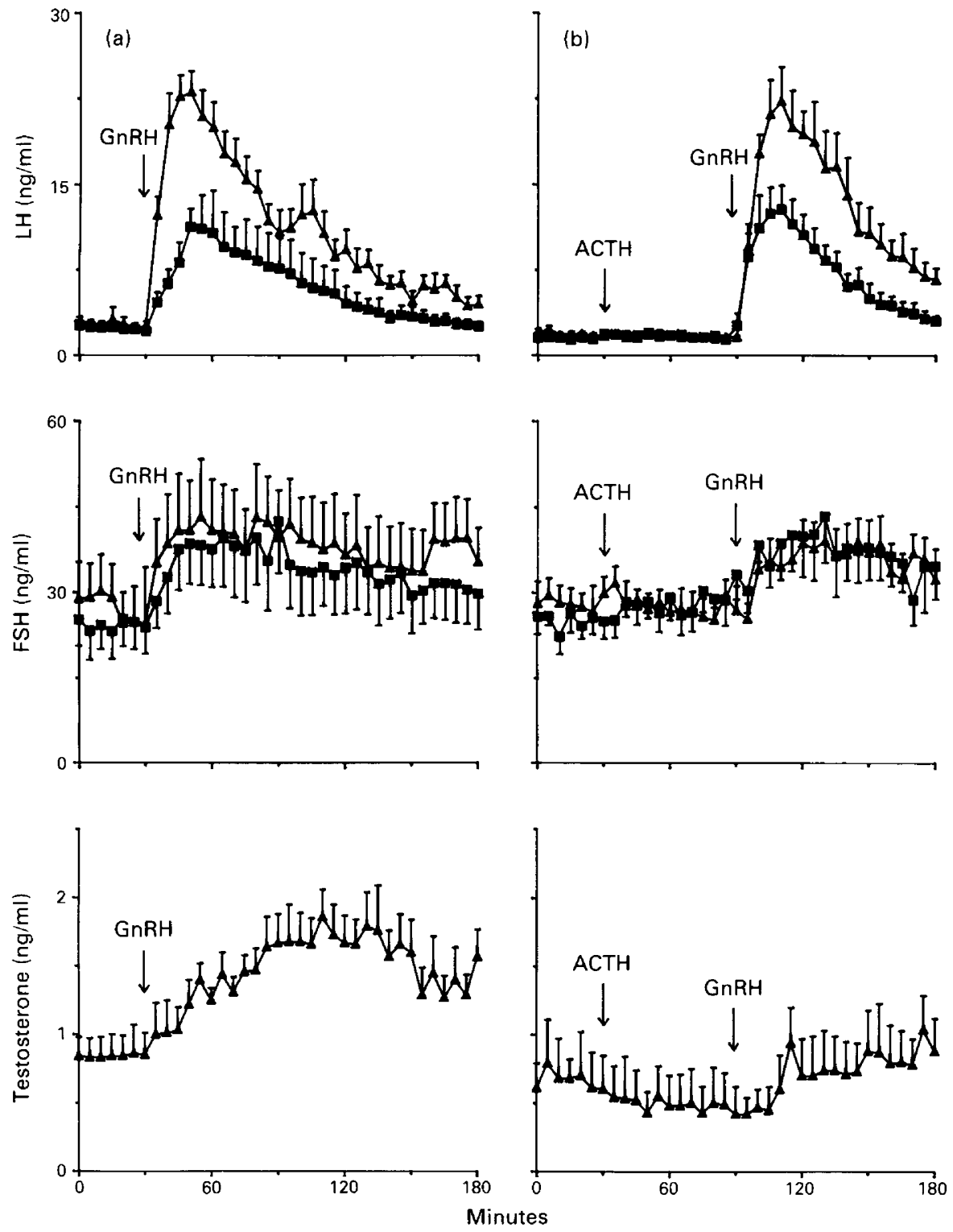

Fig. 3. Mean \pm s.e.m. serum LH, FSH and testosterone concentrations after (a) GnRH (5 animals/sex), or (b) ACTH followed $1 \mathrm{~h}$ later by $\mathrm{GnRH}(5 / \mathrm{sex})$ in male ( $\boldsymbol{\Delta})$ and female ( $\mathbf{\square})$ leopards.

demonstrated in the cheetah, tiger and North Chinese leopard (Wildt et al., 1984a; Brown et al., 1988).

The high incidence of teratospermia observed in the leopards of Sri Lanka is a common finding among many felid species. High percentages of structurally abnormal spermatozoa have also been reported in the electroejaculates of the North Chinese leopard, puma, cheetah, clouded leopard, tiger and some populations of lions (range 38-80\%) (Wildt et al., 1986b, 1987, 1988). In contrast, using the same electroejaculation procedure, males of other species such as the domestic cat, leopard cat (Prionailurus bengalensis), or known outbred lion populations produce ejaculates 
containing fewer than 30\% abnormal spermatozoa (Wildt et al., 1983, 1987; Howard et al., 1984a). Although the specific causes of teratospermia in felids are unknown, there is increasing evidence that genetic variation and hormonal status influence ejaculate characteristics. Two felid species known to have survived severe population bottlenecks and/or geographical isolation (cheetah and lion) exhibit low genetic diversity, poor ejaculate quality and depressed basal testosterone secretion (Wildt et al., 1983, 1984b, 1987; O'Brien et al., 1985, 1987). Androgens are essential for most stages of spermatogenesis (Mann \& Lutwak-Mann, 1981); however, it is not known whether circulating testosterone concentrations in some felid species with compromised sperm morphology are suboptimal for sustaining normal spermatogenic function. The observation of depressed testosterone values in some species or populations, despite similar immunoreactive concentrations of the controlling hormone LH (Goodrowe et al., 1985; Wildt et al., 1986a, 1987, 1988; Brown et al., 1988), suggests that compromised genotype probably affects the gonad and not the pituitary. However, alterations in bioactivity of the secreted gonadotrophins may also be involved.

A parallel study of genetic diversity in the leopards of Sri Lanka $(\mathrm{N}=33)$ revealed a low frequency of polymorphism $(\mathrm{P}=4 \%)$ and average heterozygosity $(\overline{\mathrm{H}}=0.014)$ (based on a survey of 50 alloenzyme loci: Miththapala et al., 1989). The extent of genetic monomorphism in this population was not as marked as that observed in the cheetah and Asian lion $(P=0 \% ; \bar{H}=0)$, but was comparable to that of a lion population geophysically isolated within a volcanic caldera in the Serengeti ecosystem $(\mathrm{P}=4 \% ; \overline{\mathrm{H}}=0.015)$ and greater than that for the clouded leopard $(\mathrm{P}=6 \%$; $\overline{\mathrm{H}}=0.023)$, tiger $(\mathrm{P}=10 \% ; \overline{\mathrm{H}}=0.035)$, free-ranging African lion in the Serengeti $(\mathrm{P}=11 \%$; $\overline{\mathrm{H}}=0.038$ ) (Newman et al., 1985; O'Brien et al., 1987) and domestic cat $(\mathrm{P}=21 \% ; \overline{\mathrm{H}}=0.082)$ (O'Brien, 1980). Today, human encroachment and the destruction of wildlife habitats, including those in Sri Lanka, increase the incidence of population fragmentation and isolation, thereby decreasing the ability of these species to remain genetically diverse. The present data support previous assertions that isolated populations are susceptible to genetically derived alterations in normal physiological function.

We thank Dr J. J. Reeves, Washington State University, USA, for the gift of LH antiserum (JJR $\$ 5)$; Dr J. A. Dias, Albany Medical College, USA, for the FSH antiserum ( $\$ 178)$; Dr L. E. Reichert, Jr, Albany Medical College, USA, for the sheep LH and FSH for iodination and dog LH standard preparation; NIADDK for the sheep FSH standard preparation; Dr S. J. O'Brien and staff, National Cancer Institute, USA, for co-operation in the assaying of steroid hormones; the animal keepers and personnel of the National Zoological Gardens of Sri Lanka for assistance in handling the animals and collecting blood samples; J. Daniel and the Bombay Natural History Society for providing essential logistic support; and J. Z. Koeser for manuscript preparation. This study was supported by Friends of the National Zoo (FONZ), the Mars Foundation, the Women's Committee of the Smithsonian Associates, Smithsonian Research Opportunities Fund and Smithsonian Special Foreign Currency Program. Blood samples were collected in full compliance with specific Federal U.S. Fish and Wildlife permits (CITES; Endangered and Threatened Species) issued to the National Zoological Park, Smithsonian Institution.

\section{References}

Baldwin, D.M. \& Sawyer, C.H. (1974) Effects of dexamethasone on LH release and ovulation in the cyclic rat. Endocrinology 94, 1397-1403.

Bambino, T.H. \& Hsueh, A.J.W. (1981) Direct inhibitory effect of glucocorticoids upon testicular luteinizing hormone receptor and steroidogenesis in vivo and in vitro. Endocrinology 108, 2142-2148.

Barnes, M.A., Kazmer, G.W., Birrenkott, G.P. \& Grimes, L.W. (1983) Induced gonadotropin release in adreno- corticotropin-treated bulls and steers. J. Anim. Sci. 56, 155-161.

Brown, J.L., Goodrowe, K.L., Simmons, L.G., Armstrong, D.L. \& Wildt, D.E. (1988) Evaluation of the pituitarygonadal responses to $\mathrm{GnRH}$, and adrenal status, in the leopard (Panthera pardus japonensis) and tiger (Panthera tigris). J. Reprod. Fert. 82, 227-236.

Carter, K.K., Chakraborty, P.K., Bush, M. \& Wildt, D.E. (1984) Effects of electroejaculation and ketamine-HCl 
on serum cortisol, progesterone, and testosterone in the male cat. J. Androl. 5, 431-437.

Deraniyagala, P.E.P. (1949) Some Vertebrate Animals of Ceylon. Natl. Museums Ceylon Pictorial Series, Vol. 1. Natl. Museum of Colombo. Plate 94.

Deraniyagala, P.E.P.(1956) The Ceylon leopard, a distinct subspecies. Spolia Zeylanica 28, 115-116.

Doerr, P. \& Pirke, K.M. (1976) Cortisol-induced suppression of plasma testosterone in normal adult males. J. clin. Endocr. Metab. 43, 622-629.

Ellerman, J.R. \& Morrison-Scott, T.C.S. (1951) Checklist of Palearctic Indian Mammals 1758-1946. British Museum of London.

Goodrowe, K.L., Chakraborty, P.K. \& Wildt, D.E. (1985) Pituitary and gonadal response to exogenous LHreleasing hormone in the male domestic cat. $J$. Endocr. 105, 175-181.

Guggisberg, C.A.W. (1975) In Wild Cats of the World, pp. 216-246. Taplinger Publishing Co., New York.

Howard, J.G., Bush, M., Hall, L.L. \& Wildt, D.E. (1984a) Morphological abnormalities in spermatozoa of 28 species of non-domestic felids. Proc. 10th Int. Congr. Anim. Reprod. \& A.I. Urbana, Vol. II, p. 57, Abstr.

Howard, J.G., Bush, M., de Vos, V. \& Wildt, D.E. (1984b) Electroejaculation, semen characteristics and testosterone concentrations of free-ranging African elephants (Loxodonta africana). J. Reprod. Fert. 72, 187-195.

Howard, J.G., Bush, M. \& Wildt, D.E. (1986) Semen collection, analysis and cryopreservation in nondomestic mammals. In Current Therapy in Theriogenology, pp. 1047-1053. Ed. D. Morrow. W.B. Saunders Company, Philadelphia.

Liptrap, R.M. \& Raeside, J.I. (1975) Increase in plasma testosterone concentration after injection of adrenocorticotrophin into the boar. J. Endocr. 66, 123-131.

Liptrap, R.M. \& Raeside, J.I. (1983) Effect of cortisol on the response to gonadotrophin releasing hormone in the boar. J. Endocr. 97, 75-81.

Mann, T. \& Lutwak-Mann, C.L. (1981) Testis and testicular semen. In Male Reproductive Function and Semen, pp. 90-95. Springer-Verlag, New York.

Matteri, R.L., Watson, J.G. \& Moberg, G.P. (1984) Stress or acute adrenocorticotrophin treatment suppresses LHRH-induced release in the ram. J. Reprod. Fert. 72, 385-393.

Miththapala, S., Seidensticker, J., Phillips, L.G., Goodrowe, K.L., Fernando, S.B.U., Forman, L. \& O'Brien, S.J. (1989) Genetic variation in Sri Lankan leopards. Zoo Biol. (in press).

Newman, A., Bush, M., Wildt, D.E., van Dam, D., Frankenhuis, M., Simmons, L., Phillips, L. \& O'Brien, S.J. (1985) Biochemical variation in eight endangered or threatened felid species. J. Mammal. 66, 256 267.

O'Brien, S.J. (1980) The extent and character of biochemical genetic variation in the domestic cat (Felis catus). J. Hered. 71, 2-8.

O'Brien, S.J., Roelke, M.E., Marker, L., Newman, A., Winkler, C.W., Meltzer, D., Colly, L., Everman, J., Bush, M. \& Wildt, D.E. (1985) Genetic basis for species vulnerability in the cheetah. Science, N.Y. 227, $1428-1434$.

O'Brien, S.J., Martenson, J.S., Packer, C., Herbst, L., de
Vos, V., Ott-Joslin, J., Wildt, D.E. \& Bush, M. (1987) Biochemical genetic variation in zoo geographic isolates of African and Asiatic lions. Natl. Geog. Res. 3, $114-124$

Pearce, G.P., Paterson, A.M. \& Hughes, P.E. (1988) Effect of short-term elevations in plasma cortisol concentration on LH secretion in prepubertal gilts. $J$. Reprod. Fert. 83, 413-418.

Pursel, V.G. \& Johnson, L.A. (1974) Glutaraldehyde fixation of boar spermatozoa for acrosomal evaluation. Theriogenology 1, 63-68.

Saez, J.M., Morera, M., Haour, F. \& Evain, D. (1977) Effects of in vivo administration of dexamethasone, corticotropin and human chorionic gonadotropin on steroidogenesis and protein and DNA synthesis of testicular interstitial cells in prepubertal rats. Endocrinology 101, 1256-1263.

Sapolsky, R.M. (1985) Stress-induced suppression of testicular function in the wild baboon: Role of glucocorticoids. Endocrinology 116, 2273-2278.

Seidensticker, J., Sunquist, M.E. \& McDougal, C. (1989) Leopards living at the edge of the Royal Chitwan National Park, Nepal. J. Bombay Nat. Hist. Soc. (in press).

Smithers, R.H.N. (1971) A family Felidae. In The Mammals of Africa-An Identification Manual part 8.1, pp. 1-10. Eds J. Mester \& H. Hetzer. Smithsonian Institution Press, Washington D.C.

Wildt, D.E., Bush, M., Howard, J.G., O'Brien, S.J., Meltzer, D., van Dyk, A., Ebedes, H. \& Brand, D.J. (1983) Unique seminal quality in the South African cheetah and a comparative evaluation in the domestic cat. Biol. Reprod. 29, 1019-1025.

Wildt, D.E., Chakraborty, P.K., Meltzer, D. \& Bush, M. (1984a) Pituitary and gonadal response to LH releasing hormone administration in the female and male cheetah. J. Endocr. 101, 51-56.

Wildt, D.E., Meltzer, D., Chakraborty, P.K. \& Bush, M. (1984b) Adrenal-testicular-pituitary relationships in the cheetah subjected to anesthesia/electroejaculation. Biol. Reprod. 30, 665-672.

Wildt, D.E., Howard, J.G., Chakraborty, P.K. \& Bush, M. (1986a) Reproductive physiology of the clouded leopard: II. A circannual analysis of adrenal-pituitarytesticular relationships during electroejaculation or after an adrenocorticotropin hormone challenge. Biol. Reprod. 34, 949-959.

Wildt, D.E., Howard, J.G., Hall, L.L. \& Bush, M. (1986b) Reproductive physiology of the clouded leopard: I. Electroejaculates contain high proportions of pleiomorphic spermatozoa throughout the year. Biol. Reprod. 34, 937-947.

Wildt, D.E., Bush, M., Goodrowe, K.L., Packer, C., Pusey, A.E., Brown, J.L., Joslin, P. \& O'Brien, S.J. (1987) Reproductive and genetic consequences of founding isolated lion populations. Nature, Lond. 329, 328-331.

Wildt, D.E., Phillips, L.G., Simmons, L.G., Chakraborty, P.K., Brown, J.L., Howard, J.G., Teare, A. \& Bush, M. (1988) A comparative analysis of ejaculate and hormonal characteristics of the captive male cheetah, tiger, leopard and puma. Biol. Reprod. 38, 245-255.

Received 19 July 1988 